\title{
A new species of Begonia (Begoniaceae) from the Moluccas, Indonesia
}

\author{
I.M. Ardaka ${ }^{1} \&$ W.H. Ardi ${ }^{2}$ \\ ${ }^{1}$ Bali Botanic Garden - Indonesian Institute of Sciences (LIPI) \\ Candikuning, Baturiti, Tabanan 82191, Bali, Indonesia \\ ardhaimade@gmail.com \\ ${ }^{2}$ Center for Plant Conservation Botanic Gardens Indonesian Institute of \\ Sciences (LIPI), Jl. Ir. Juanda No. 13, PO.BOX. 309, Bogor 16003 \\ wisnu.handoyo.ardi@lipi.go.id
}

\begin{abstract}
A new species of Begonia, Begonia mufidahkallae Ardaka \& Ardi, is described from Sawai, Seram Utara District, Seram Island, Indonesia. The species is endemic to Seram Island and belongs to Begonia section Petermannia.
\end{abstract}

Keywords. Begonia section Platycentrum, Begonia section Sphenanthera, limestone, lithophytic

\section{Introduction}

Begonia is one of the largest genera of angiosperms, comprising 1944 accepted species which are distributed across the tropics (Hughes et al., 2015, continuously updated). Among the regions of Indonesia, the Begonia flora of the Moluccas is one of the most poorly known due to the lack of collections from the islands. In recent years, four new species have been described, raising the total number of accepted species from the Moluccas to nine (Wiriadinata, 2012; Ardi et al, 2014; Ardi \& Thomas, 2015; Ardhaka et al., 2016; Undaharta \& Ardi, 2016) (see Table 1).

In order to improve our understanding of Begonia from the Moluccas, several expeditions to the archipelago have been carried out by Bali Botanic Gardens during 2011-2014. These expeditions have resulted in collections of undescribed species which are now cultivated in the Bali and Bogor Botanic Gardens. Here we report the discovery of another new species, which we are calling Begonia mufidahkallae, from material collected on Seram Island. Like the majority of Begonia species from the Moluccas, this new species is included in Begonia section Petermannia as it has the typical characters of the section: protogynous inflorescences, male flowers with two tepals, anthers with unilaterally positioned slits, five-tepaled female flowers, twoflowered female inflorescences or solitary female flowers, three-locular ovaries with axile placentation and bilamellate placentae, and fruits with equal or subequal wings (Doorenbos et al., 1998; Moonlight et al., 2018). All available specimens from BO, E, $\mathrm{K}$, L and SING have been consulted, and hence it must be assumed, at least until more intensive collecting in the Moluccas reveals otherwise, that the species described here has a very restricted distribution range. 
Table 1. Begonia species from the Moluccas.

\begin{tabular}{ll}
\hline Section & Species \\
\hline Petermannia & Begonia aketajawensis Ardi \& D.C.Thomas \\
& Begonia galeolepis Ardi \& D.C.Thomas \\
& Begonia holosericea (Teijsm. \& Binn.) Teijsm. \& Binn. \\
& Begonia holosericeoides Ardi \& D.C.Thomas \\
& Begonia manuselaesis Ardhaka \& Ardi \\
& Begonia nephrophylla Undaharta \& Ardi \\
& Begonia sageaensis Wiriad. \\
& Begonia aptera Blume \\
Platycentrum & Begonia longifolia Blume \\
\hline
\end{tabular}

\section{Species description}

Begonia mufidahkallae Ardaka \& Ardi, sp. nov. (§Petermannia)

Begonia mufidahkallae is similar to Begonia flacca Irmsch. in the habit (semierect or appressed to substrate at the base and distally erect) but differs in having red multicellular hairs on the stem, petioles and lower surface of leaves (vs white), shorter petioles $(2-6 \mathrm{~cm}$ vs $6-17 \mathrm{~cm}$ ); denticulate to serrulate leaf margins (vs serrate to biserrate or shallowly lobed), paniculate-cymose male inflorescences (vs simple monochasia) and fruits on hanging, 10-20 mm long pedicels (vs fruit not pendulous, pedicels 3-8.5 mm long). - TYPE: Cultivated from material collected in the wild in Indonesia, Sawai, Seram Utara district, Seram Island, S 02 58.088'E129¹2.093', 22 February 2016, vouchered and selected as type as Wisnu Ardi WI 104 (holotype BO; isotypes KRB). (Fig. 1).

Perennial, monoecious herb, semi-erect or appressed to substrate at the base and distally erect, to c. $30 \mathrm{~cm}$ tall. Stem branched; internodes 2-6 cm long, brownish-reddish, with microscopic glandular hairs and a sparse indumentum of multicellular red hairs, c. 0.5-1.5 mm long. Stipules caducous, 8-12 $\times 4-5.5 \mathrm{~mm}$, elliptic, slightly anisophyllus, with an abaxially slightly prominent midrib, apex narrowed into a bristle projecting up to $1.5 \mathrm{~mm}$, reddish greenish, translucent at the margin, abaxially glabrous. Leaves: petioles $2-6 \mathrm{~cm}$ long, adaxially shallowly channelled, reddish, moderately covered with red hairs, denser on the younger parts, c. $1.5 \mathrm{~mm}$ long; lamina $9.5-14 \times 7-9.5 \mathrm{~mm}$, asymmetric, ovate to elliptic, base cordate and lobes not or just slightly overlapping, apex acuminate, margin denticulate to serrulate, adaxial surface green-reddish, with reddish veins toward the base and pale green towards the margin, glabrous, abaxially pale green-reddish, sparsely hairy on the veins only; venation palmate-pinnate, primary veins 6-7, actinodromous, secondary veins craspedodromous. Inflorescences 


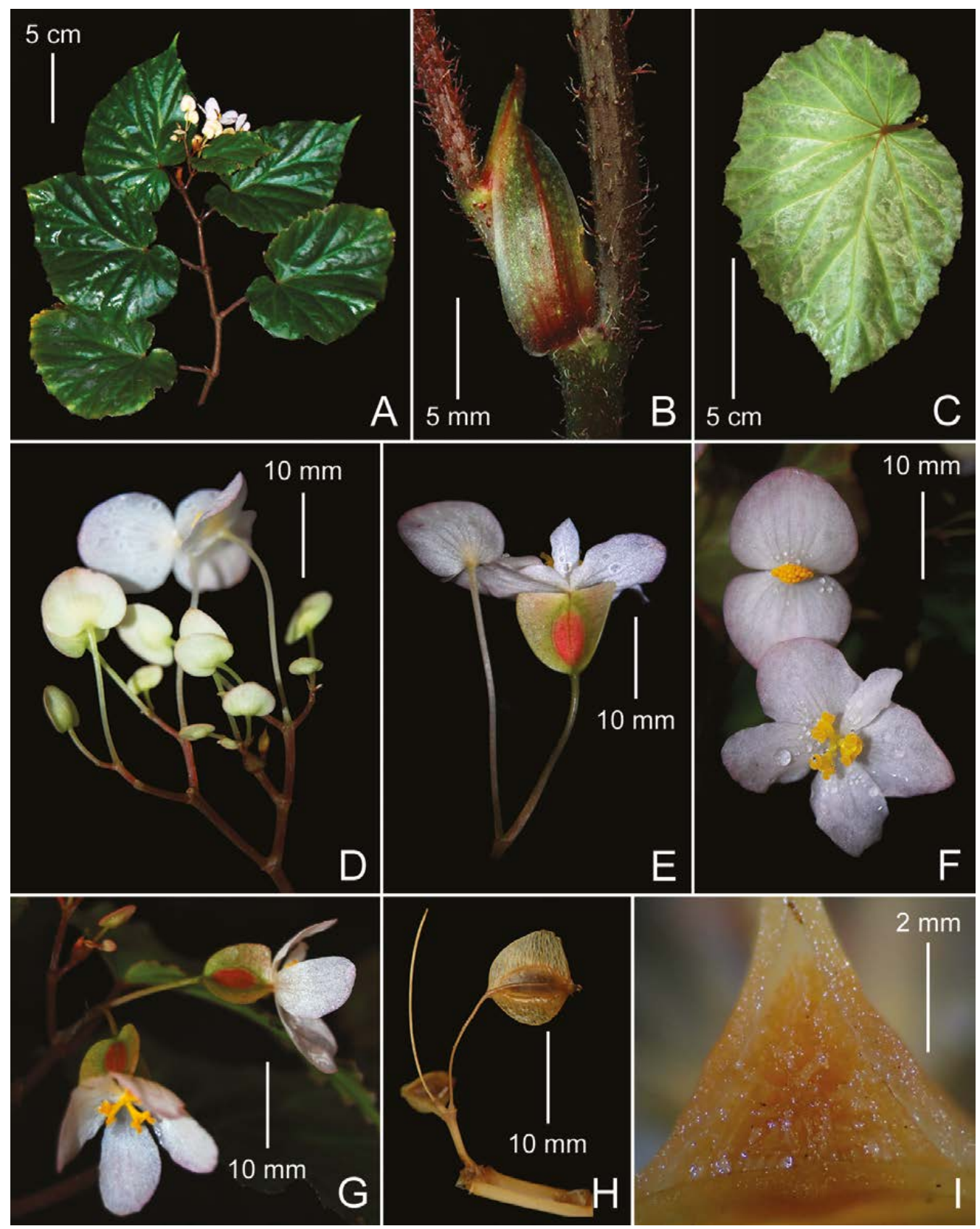

Fig. 1. Begonia mufidahkallae Ardaka \& Ardi. A. Habit. B. Stipule. C. Lamina abaxial surface. D. Male inflorescence. E. Female and male flower side view. F. Female and male flower front view. G. Female inflorescence. H. Infructescence. I. Ovary cross section (middle part). (Photos: W.H. Ardi). 
protogynous; female inflorescences 2-flowered, sometimes associated with a single male flower in between, or single female flower with single male flower, peduncles c. $5 \mathrm{~mm}$ long, glabrescent to glabrous; male inflorescences paniculate-cymose with 3-4 dichasial-monochasial partial inflorescences on up to $2 \mathrm{~cm}$ long peduncles in the basal part, each with up to 8 flowers, bracts caducous. Male flowers: pedicels 1.5-3.5 $\mathrm{cm}$ long, white, greenish or reddish, glabrous; tepals 2, white tinged pink, 9-12 $\times$ 11-14 mm, broadly ovate, base slightly cordate, apex rounded, outer surface glabrous; androecium of c. 26-27 stamens, yellow, filaments up to c. $0.3-0.8 \mathrm{~mm}$ long, slightly fused at the very base, anthers up to c. $0.7-1 \mathrm{~mm}$ long, oblong to narrowly obovate, dehiscing through unilaterally positioned slits that are c. $1 / 2$ as long as the anthers. Female flowers: pedicels 1-2 cm long, reddish, glabrous; tepals 5, white tinged pink, unequal, one smaller 8-10 $\times 4-5 \mathrm{~mm}$, elliptic, the four larger 11-12 $\times 8-10 \mathrm{~mm}$, ovate, outer surface glabrous; ovary (excluding wings) $8-10 \times 4.5-5 \mathrm{~mm}$, ellipsoid, pink to red, glabrous, locules 3 , placentation axile, placentae bilamellate, wings 3 , subequal wing slightly larger than two others to unequal, pale green-reddish, base rounded, apex subtruncate to truncate, up to 5-7 mm at widest point (apically or subapically); style c. $6 \mathrm{~mm}$ long, basally fused, 3-branched, each stylodium bifurcate in the stigmatic region, stigmatic surface a spirally twisted papillose band, orange. Fruits: peduncles c. $5 \mathrm{~mm}$ long; pedicels 1.5-2 cm long, pendulous; seed-bearing part ellipsoid, 8-11 $\times 4.5-5$ $\mathrm{mm}$ (excluding the wings), glabrous, dehiscent, splitting along the wing attachment, wings as for ovary, up to $8 \mathrm{~mm}$ at the widest point (apically or subapically). Seeds barrel-shaped, c. $0.2-0.6 \mathrm{~mm}$ long.

Distribution. Indonesia, Seram Island, Sawai, Seram Utara District.

Habitat. Growing lithophytically on limestone rock, half shade in the lowland limestone forest at $53 \mathrm{~m}$ elevation.

Etymology. The specific epithet is in honour of Mrs Mufidah Jusuf Kalla, the wife of the Vice President of the Republic of Indonesia, Jusuf Kalla.

Provisional IUCN conservation assessment. Data Deficient (DD). Begonia mufidahkallae is known from a single locality in an unprotected area, Sawai, Seram Utara district. Further exploration is required to assess the species' current range.

Notes. The semi-erect habit is a rare character in Begonia section Petermannia from Wallacea, only being known in several species from Sulawesi and Moluccas. These include Begonia galeolepis Ardi \& D.C. Thomas, B. holosericea (Teijsm. \& Binn.) Teijsm. \& Binn., B. holosericeoides Ardi \& D.C.Thomas and B. sageaensis Wiriad. Begonia mufidahkallae can be easily differentiated from all these species by the slender stem (diameter 4-6 $\mathrm{mm}$ ) with simple red trichomes, while all other species have thicker stem (diameter 10-12 mm) with an indumentum of branched hairs $(B$. holosericea, $B$. holosericeoides and B. sageaensis) or fleshy, red, flattened scales (B. galeolepis). The male inflorescence of Begonia mufidahkallae can also distinguish 
it from these other species: in B. mufidahkallae the male partial inflorescences are arranged dichasialy, whilst in the B. holosericea, B. holosericeoides, B. galeolepis and $B$. sageaensis they are arranged monochasially. The pedicel length of female flower is a further difference, in $B$. mufidahkallae the pedicel is glabrous and the shortest among $(1-2 \mathrm{~cm})$ of three species (B. holosericea is 3-4 cm and hairy; B. holosericeoides is $2.2-3.1 \mathrm{~cm}$ and sparsely hairy; $B$. galeolepis is up to $4 \mathrm{~cm}$ and sparsely hairy), whereas $B$. sageansis has similar length with $B$. mufidahkallae, however it can be differentiated by sparse indumentum of red hairs on the ovary and equal wings ( vs. ovary glabrous and unequal wings).

ACKNOWLEDEMENTS. The authors would like to express gratitude to Ir. I Nyoman Lugrayasa, the former director of Kebun Raya Bali for his support of Begonia research, and the Bali Botanic Gardens expedition team (Putu Suparta, Wayan Mastre, Burhani and Nyoman Tiwirya), and to the curators of A, BO, E, K, L and SING for allowing us access to herbarium material.

\section{References}

Ardhaka, I.M., Ardi, W.H., Undaharta, N.K.E. \& Tirta, I.G. (2016). A new species of Begonia from Manusela National Park, Seram. Reinwardtia 15(1): 61-64.

Ardi, W.H., Kusuma, Y.W.C, Lewis, C.E., Risna, R.R, Wiriadinata, H., Abdo, M.E. \& Thomas, D.C. (2014). Studies on Begonia (Begoniaceae) of the Molucca islands I: Two new species from Halmahera, Indonesia, and an updated description of Begonia holosericea. Reindwartia 14(1): 19-26.

Ardi, W.H. \& Thomas, D.C. (2015). Studies on Begonia (Begoniaceae) of the Moluccas II : a new species from Seram, Indonesia. Gard. Bull. Singapore 67: 297-303. doi:10.3850/ s2382581215000253.

Doorenbos, J.M., Sosef, S.M. \& De Wilde, J.J.F.E. (1998). The sections of Begonia including descriptions, keys and species lists. Studies in Begoniaceae VI. Wageningen Agric. Univ. Pap. 98(2): 1-266.

Hughes, M., Moonlight, P., Jara, A., Tebbitt, M., Pullan, M. (2015, continuously updated). Begonia Resource Centre. http://padme.rbge.org.uk/begonia/. (Accessed on 30 September 2019).

Moonlight, P.W., Ardi, W.H., Padilla, L.A., Chung, K.-F., Fuller, D., Girmansyah, D., Hollands, R., Mahardika, A., Jara-Muñoz, A., Kiew, R., Marasinghe, L.D.K., Leong, W.-C., Liu, Y., O’Connor, M., Peng, C.-I, Pérez, Á.J., Phutthai, T., Pullan, M., Rajbhandary, S., Reynel, C., Rubite, R.R., Julia, S., Scherberich, D., Shui, Y.-M., Tebbitt, M.C., Thomas, D.C., Zaini, N.H. \& Hughes, M. (2018). Dividing and conquering the fastest growing genus: towards a natural sectional classification of the mega-diverse genus Begonia (Begoniaceae). Taxon 67: 267-363.

Undaharta, N.K.E. \& Ardi, W. H. (2016). Studies on Begonia (Begoniaceae) of the Moluccas III: A new Begonia from Seram, Indonesia. Gard. Bull. Singapore 68(2): 279-285.

Wiriadinata, H. (2012). A new species of Begonia (Begoniaceae) from Sagea Lagoon, Weda Bay, Halmahera Island, North Moluccas, Indonesia. Reinwardtia 13(3): 263-270. 
